\title{
SCREENING OF NITROGEN FIXERS FROM RHIZOSPHERIC BACTERIAL ISOLATES ASSOCIATED WITH IMPORTANT DESERT PLANTS
}

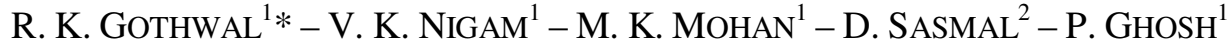 \\ ${ }^{1}$ Birla Institute of Scientific Research, Statue Circle, Jaipur-302 001, INDIA. \\ ${ }^{2}$ Birla Institute of Technology, Mesra, Ranchi - 835 215, INDIA \\ *Corresponding author \\ e-mail: r_gothwal@yahoo.com
}

(Received $7^{\text {th }}$ September 2006 ; accepted $24^{\text {th }}$ October 2007)

\begin{abstract}
Free living nitrogen fixers represent a range of microorganisms including bacteria living on plant residues (saprophytes), bacteria which live entirely within plants (endophytes) and bacteria living in close association with the plant roots (rhizobacteria). We have isolated a number of rhizosphere associated bacteria from two of the hot arid zone plants and explored these in terms of nitrogen fixing ability both in solid and liquid culture conditions. The maximum coloring zone was developed in T-1 (22 $\mathrm{mm}$ ) whereas minimum was in T-3 $(4 \mathrm{~mm})$ in case of the C. polygonoides associated bacterial community. The coloring zone was found maximum in TS-2 $(27 \mathrm{~mm})$ and minimum in TS-1 $(11 \mathrm{~mm})$, in case of isolates associated with rhizosphere of $\mathrm{L}$. sindicus. The highest and lowest acetylene reduction activity (ARA) was detected in TS-13 (8303 n moles / $24 \mathrm{~h}$ ) and T-10 (1658 n moles / $24 \mathrm{~h}$ ), respectively. Keywords Hot arid region, rhizospheric bacteria, nitrogen fixation, ARA, malate media.
\end{abstract}

\section{Introduction}

The rhizosphere or the zone of influence around plant roots harbors a multitude of microorganisms that are affected by both abiotic and biotic stresses. Among these are the dominant rhizobacteria that prefer living in close vicinity to the root or on its surface and play a crucial role in soil health and plant growth [6]. These groups of bacteria are important as they are involved in various soil biochemical processes viz. fixation of atmospheric nitrogen, solubilization of minerals such as phosphorus, production of siderophores that solubilize and sequester iron or production of plant growth regulators [9].

Nitrogen $(\mathrm{N})$ is the key plant nutrient required for plant growth. The elemental $\mathrm{N}$ is abundant in the earth's atmosphere [12] however; most of the tropical soils are deficient in available N. In ecosystems with low inputs and without any fertilization or soil amendments by humans, the nutrients available to plants come either from atmospheric inputs [3] or from biological fixation [15]. Biological nitrogen fixation (BNF) is one way of converting elemental nitrogen into plant usable form. A number of microbes are involved in the process of $\mathrm{BNF}$, which contains nitrogenase enzyme responsible for fixing atmospheric dinitrogen into soil, thus improving the soil fertility. Therefore, it is an excellent, economically and environmentally sound source to substitute fertilizer $\mathrm{N}$ [14]. The BNF is estimated to contribute $180 \times 10^{6}$ metric tons/year globally and about $80 \%$ comes from symbiotic associations. Besides, symbiotic nitrogen fixation, the non symbiotic nitrogen fixation is also known to be of great agronomic significance [19].

The arid zone of India covers an area of $38.7 \mathrm{~m}$ ha, out of which $31.7 \mathrm{~m}$ ha comes under hot arid zone. The soils in this zone are coarse textured and covered with sand 
dunes. Low available water capacity, vulnerability to wind erosion and low fertility are major constraints along with high salinity, calcareousness and gypsiferous nature [4]. The temperature rises up to $50^{\circ} \mathrm{C}$ with average rainfall less than $200 \mathrm{~mm}$ causing the conditions more severe for most of the life forms besides poor nutritional status of the soils [1]. The plant and microbial diversity in these areas are limited, which proves their ecological importance. Sand dunes from Thar are reported to have relatively smaller population of microorganisms $\left(1.5 \times 10^{2}-5 \times 10^{4}\right.$ per $\mathrm{g}$ soil $)$ [7, 20] because of the extreme variations of environmental factors. The enhancement of soil fertility in these areas thus requires a careful management of natural resources for sustainable plant production. This involves the concept of using, improving and restoring the productive capacity and life support processes of soil [16]. Bio-inoculants production is one approach in these areas.

Two plant species (viz. Calligonum polygonoides and Lasiurus sindicus) were selected on basis of their ecological importance and well adaptability in these hot arid areas in order to study the rhizosphere associated bacterial diversity. During the investigation of plant growth promoting bacterial inoculants (development of bioinoculants) for improving plant production of the selected plant species we found some phosphate solubilizing bacteria [5] and a number of nitrogen fixing bacteria. The objective of the present investigation was to screen the plant rhizosphere associated nitrogen fixing bacterial isolates and to test their efficiency in nitrogen fixation under liquid culture conditions.

\section{Materials and methods}

\section{Study site and soil sampling}

In the western desert region of Rajasthan C. polygonoides (Phog) and L. sindicus (Sewan grass) plants are known for their involvement in the ecological maintenance by helping in the soil conservation and dune stabilization besides some economical values e. g. wood, fuel, fodder etc. Therefore, these two plants have achieved a prominence due to their adaptability in desert climatic conditions in the Western sandy plain subregion, which is one of the agroecological zone of North Western hot arid regions of India. Soil samples were collected from the rhizosphere of these two plants covering three different zones of this sub-region. These zones have been characterized by dune complex physiography and poor surface and ground water resources [4].

\section{Isolation and characterization of bacterial cultures}

Different bacterial morphotypes were isolated from $1 \mathrm{~g}$ rhizosphere soil sample on King's B media [8] as described by Gothwal et al. 2006 [5] at both $37^{\circ} \mathrm{C}$ and $50^{\circ} \mathrm{C}$ respectively and characterized the important biochemical properties using the standard protocol [17].

\section{Screening of nitrogen fixing bacteria}

Nitrogen free Malate media [13], containing bromothymol blue (BTB) as an indicator, was used for preliminary screening and incubated at $37^{\circ} \mathrm{C}$ and $50^{\circ} \mathrm{C}$ up to 24 $\mathrm{h}$. The blue coloured zone producing isolates were marked as nitrogen fixers in the solid culture conditions. The colouring zone was calculated by deducting the colony diameter from the colouring zone diameter. To determine whether these isolates were truly 
nitrogen fixers, they were further tested for their acetylene reduction activity (ARA) assay in liquid culture.

\section{Quantification of nitrogen fixation}

To quantify the nitrogen fixation the different morphotypes were inoculated in nitrogen free Malate broth in $250 \mathrm{ml}$ Erlenmeyer flasks and incubated in an orbital shaker at $180 \mathrm{rpm}$ at $37^{\circ} \mathrm{C}$ and $50^{\circ} \mathrm{C}$ temperatures for $24-48 \mathrm{~h}$. Five $\mathrm{ml}$ of well grown culture was then transferred to $45 \mathrm{ml}$ fresh sterile media and incubated for $72 \mathrm{~h}$ at the same conditions. Then $20 \mathrm{ml}$ of this enriched culture was transferred into $30 \mathrm{ml}$ capacity glass screw cap autoclaved vials and cap was replaced with subaseal. With the help of a $5 \mathrm{ml}$ sterile syringe $3 \mathrm{ml}$ air was replaced with same amount of acetylene gas and again incubated in shaker up to $24 \mathrm{~h}$. Nitrogen fixation of the isolates was quantified by measuring the ethylene production by acetylene reduction assay. Analysis of the produced ethylene was accomplished by gas chromatography (Nucon-5765, AIMIL Instruments) using Porapak N column $(200 \times 0.2 \mathrm{~cm})$ equipped with a flame ionization detector (FID) in isocratic condition. The operating conditions were as follows: temperature of oven $80^{\circ} \mathrm{C}$; the injector temperature was kept $200^{\circ} \mathrm{C}$; and the detector temperature was maintained at $200^{\circ} \mathrm{C}$. The flow of $\mathrm{N}_{2}$ gas was maintained $42 \mathrm{ml} / \mathrm{min}$, $\mathrm{H}_{2}$ at a flow rate of $64 \mathrm{ml} / \mathrm{min}$ and air at a flow rate of $42 \mathrm{ml} / \mathrm{min}$ respectively. One $\mathrm{ml}$ of sample gas was injected and the area of ethylene was calculated against the standard ethylene (Spancan Calibration Gas, Spantach Products, England). The amount of ethylene produced is represented in the terms of nano moles of ethylene formed in 20 $\mathrm{ml}$ of broth at $30^{\circ} \mathrm{C}$ after $24 \mathrm{~h}$ of incubation. All the experiments were conducted in triplicate along with a control (without inoculation). The mean values of each experiment were calculated and reported.

\section{Results and discussion}

More than fifty different colonies were isolated during the study of rhizosphere associated bacterial species in case of $C$. polygonoides and L. sindicus. In continuation of the work towards development of growth promoting inoculants we found that there is a large number of free nitrogen fixers associated with the rhizosphere of these two plant species.

\section{Screening of nitrogen fixers}

The nitrogen fixing bacteria were preliminary screened on nitrogen free Malate agar media containing BTB as an indicator. Different isolates associated with rhizosphere of $C$. polygonoides and $L$. sindicus were cultivated at different temperatures $\left(37^{\circ} \mathrm{C}\right.$ and $50^{\circ} \mathrm{C}$ ) to observe the growth characteristics. Figure 1 depicts the highest and lowest zones of coloration developed by both of the plant associated rhizotypes. Isolates T-1, 2, $3,4,5,6,8,10$, T-22 and TS-1, 2, 3, 4, 5, 11, 12, 16, 17, 18, TS-20 were found to grow maximally at $37^{\circ} \mathrm{C}$. Similarly, T-11, 12, 13, 14, 15, 17, 20, 21, T-23 and TS-6, 7, 8, 9, $13,14,15$, TS- 19 were found to grow at $50^{\circ} \mathrm{C}$. The maximum zone of coloration in case of the isolates associated with rhizosphere of Phog was observed in T-1 (22 mm) whereas; lowest value was detected in T-3 (4 mm), as shown in Figure 2. Some of the isolates which were grown on higher temperature i.e. $50^{\circ} \mathrm{C}$, also showed the zone of 
coloration on nitrogen free malate media containing BTB. In such a case, the maximum zone of coloration was detected in T-12 $(17 \mathrm{~mm})$ and minimum in T-15 $(7 \mathrm{~mm})$.

In case of the isolates associated with rhizosphere of Sewan grass, the maximum value of zone of coloration was obtained in TS-2 $(27 \mathrm{~mm})$ and minimum was detected in TS-1 $(11 \mathrm{~mm})$ as represented in Figure 3. Whereas, the maximum and minimum zone of coloration was found in TS-19 and TS-7 morphotypes, respectively, isolated at $50^{\circ} \mathrm{C}$. As compared to the control (no inoculation, no zone of coloration), the above results suggest that the zone of coloration were more in case of the isolates associated with the rhizosphere of Sewan grass.

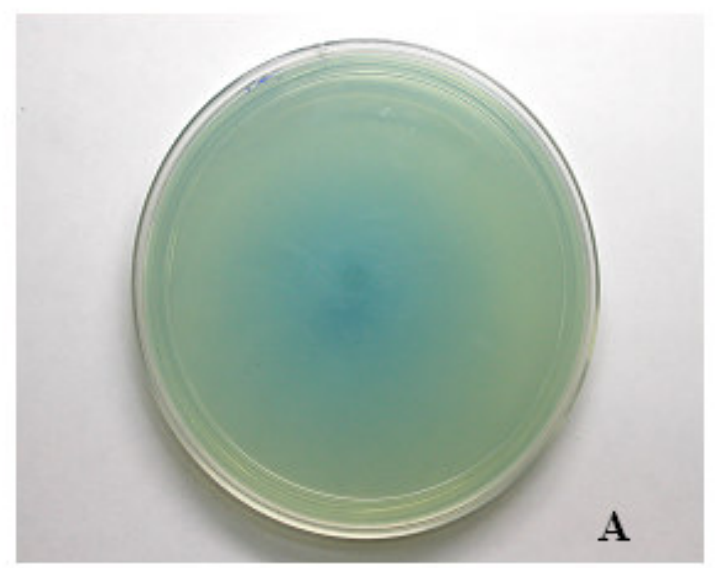

Isolate T-1

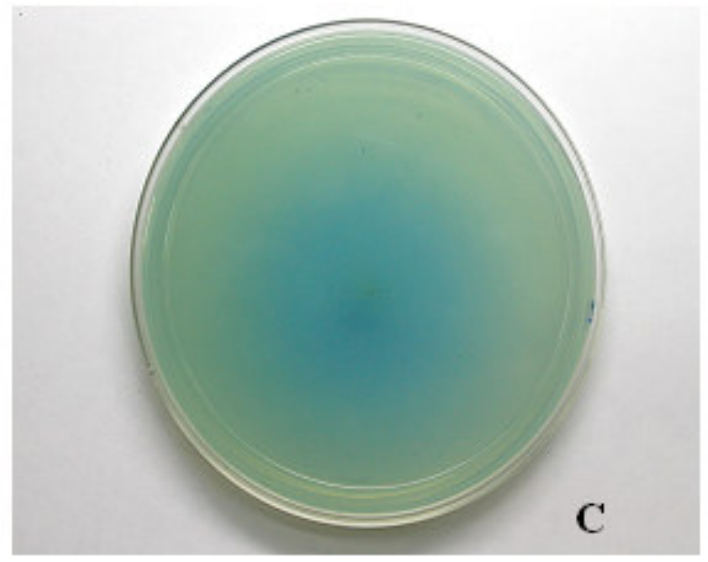

Isolate TS-2

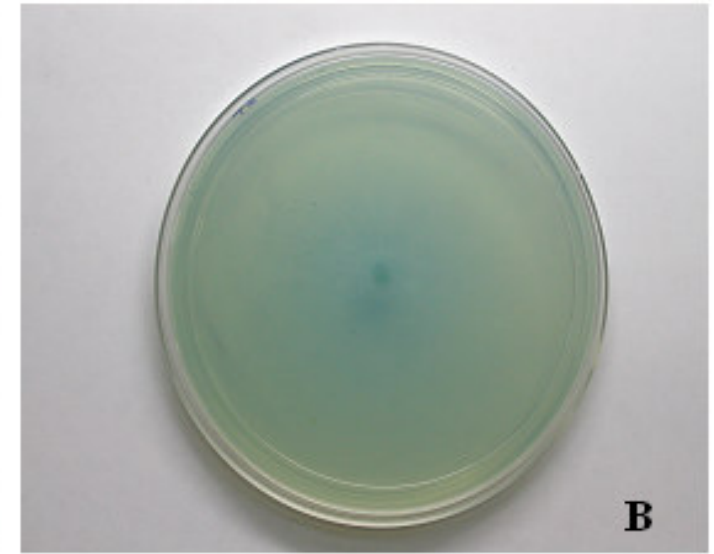

Isolate T-3

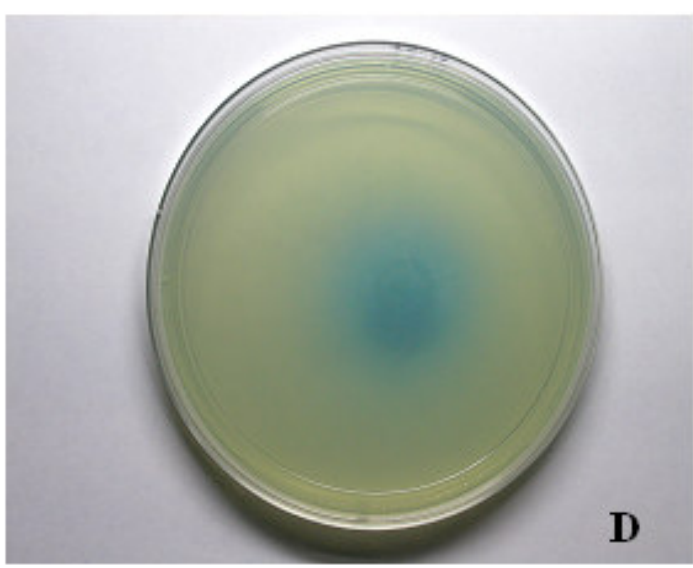

Isolate TS-1

Figure 1. Maximum and minimum zone of coloration shown by the rhizosphere associated bacterial isolates of $C$. polygonoides ( $A$ and $B$, respectively) and $L$. sindicus $(C$ and $D$, respectively) when grown at $37^{\circ} \mathrm{C}$ on $B T B$ containing $N$ free malate agar media. 


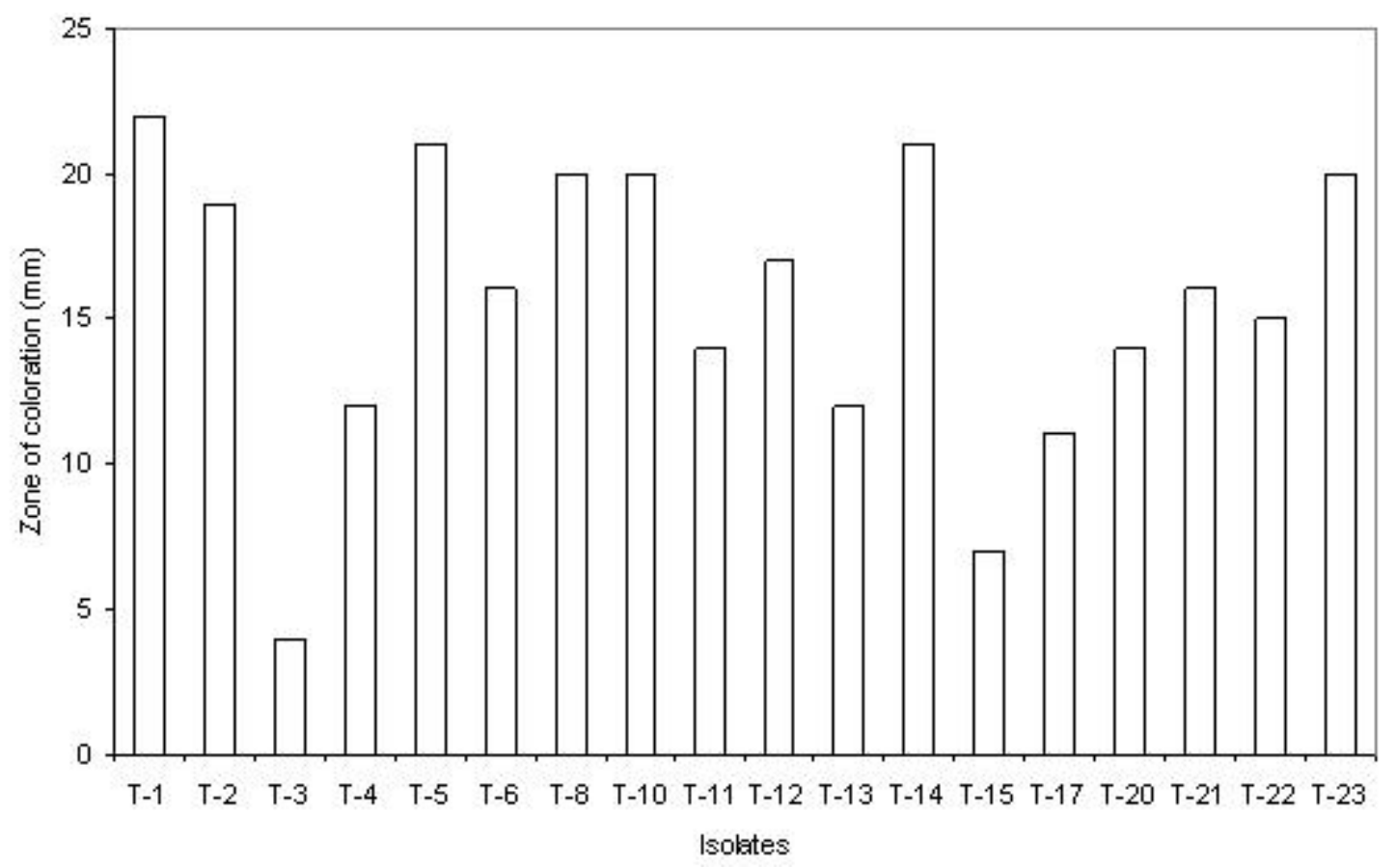

Figure 2. Zone of coloration of rhizospheric isolates associated with C. polygonoides grown at two temperatures

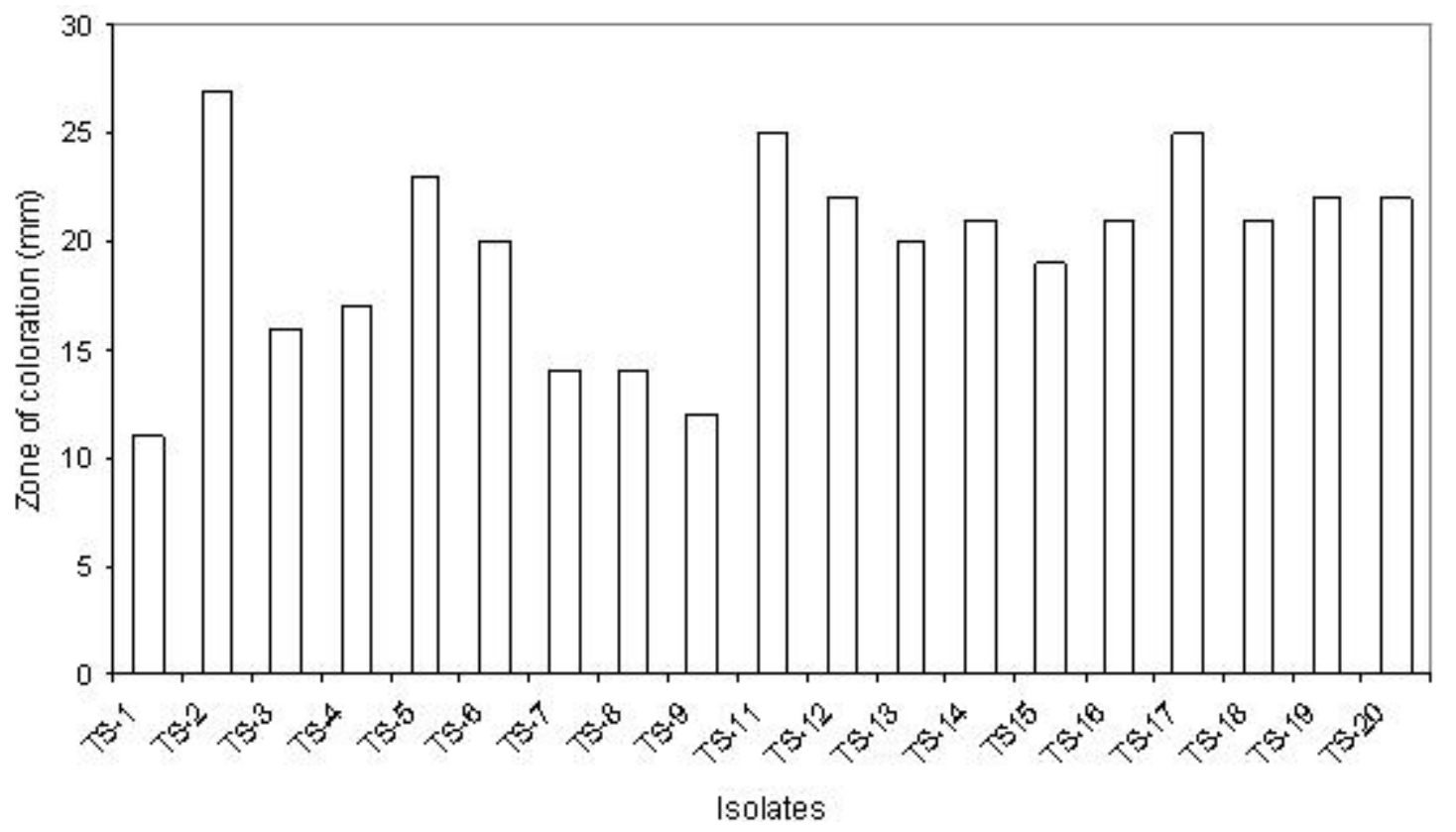

Figure 3. Zone of coloration of rhizospheric isolates associated with L.sindicus grown at two temperatures 


\section{Quantification of the nitrogen fixation}

Nitrogen fixation using all the isolates was investigated by measuring the reduction of acetylene (ARA) as described in materials and methods. It was found that some isolates which showed positive response in plate experiments, failed to show any acetylene reduction activity (ARA) in the liquid growth conditions, when analyzed by gas chromatography (T-6, 8 and all isolates of $50^{\circ} \mathrm{C}$; TS-3 and all isolates of $50^{\circ} \mathrm{C}$ except TS-13). The results of the acetylene reduction data for the Phog isolates are shown in Table 1. The maximum value of the ethylene production was obtained in isolate T-5 and lowest in T-10. Similarly, the isolates TS-13 and TS-11 were identified as highest and lowest acetylene reducing isolates in case of the Sewan grass (Table 2). When the results of ARA were compared for both the plants it was found that the strains isolated from Sewan grass, were showing higher nitrogenase activity and also the number of nitrogen fixers are more in this case.

Table 1. Acetylene reduction assay of the isolates associated with the rhizosphere of C. polygonoides

\begin{tabular}{|r|c|c|}
\hline S. No. & Isolate No. & $\begin{array}{c}\text { Ethylene produced } \\
\text { (n moles / 24 h } \text { ) }\end{array}$ \\
\hline 1. & $\mathrm{~T}-1$ & 4110.5 \\
\hline 2. & $\mathrm{~T}-2$ & 2265.6 \\
\hline 3. & $\mathrm{~T}-3$ & 2617.5 \\
\hline 4. & $\mathrm{~T}-4$ & 1763.3 \\
\hline 5. & $\mathrm{~T}-5$ & 7594.8 \\
\hline 6. & $\mathrm{~T}-10$ & 1657.7 \\
\hline 7. & $\mathrm{~T}-22$ & 2116.5 \\
\hline
\end{tabular}

Table 2. Acetylene reduction assay of the isolates associated with the rhizosphere of L. sindicus

\begin{tabular}{|r|c|c|}
\hline S. No. & Isolate No. & $\begin{array}{c}\text { Ethylene produced } \\
\text { (n moles / 24 h } \text { ) }\end{array}$ \\
\hline 1. & TS-1 & 5206.8 \\
\hline 2. & TS-2 & 4080.9 \\
\hline 3. & TS-4 & 3658.8 \\
\hline 4. & TS-5 & 3940.3 \\
\hline 5. & TS-11 & 1688.7 \\
\hline 6. & TS-12 & 3236.6 \\
\hline 7. & TS-13 & 8302.7 \\
\hline 8. & TS-16 & 6191.8 \\
\hline 9. & TS-17 & 3377.4 \\
\hline 10 & TS-18 & 4362.4 \\
\hline 11. & TS-20 & 3059.9 \\
\hline
\end{tabular}




\section{Biochemical characterization of the isolates}

Various different biochemical properties of the isolates, screened from rhizosphere of both the important desert plants are given in Table 3. The strains were found both Gram-positive and Gram-negative, as depicted in the table. The bacterial colonies included in the table 3 were isolated at $37^{\circ} \mathrm{C}$ except TS $-13\left(50^{\circ} \mathrm{C}\right)$. This thermophilic isolate was also found to grow at $37^{\circ} \mathrm{C}$ temperature (mesophilic in nature). The catalase activity was present in all isolates whereas, no isolate was found to show casein hydrolyzing, sucrose degrading activity and a negative methyl red test. The positive glucose and lactose degrading capacities were detected in T-1, T-3, TS-1, TS-18 and T3 , TS-1 isolates, respectively. Isolates T-1, TS-11 and TS-18 expressed the positive nitrate reduction and gelatin hydrolyzing activity. The maximum starch hydrolyzing activity was detected in TS-11 followed by other positive isolates. Some of the isolates (T-1, T-3, TS-1, TS-11) were also found to have the positive urease activity.

Table 3. Biochemical characteristics of nitrogen fixing bacterial isolates from the rhizosphere of two hot arid region plants

\begin{tabular}{|c|c|c|c|c|c|c|c|c|c|c|c|c|}
\hline $\begin{array}{c}\text { Plant } \\
\text { rhizosphere }\end{array}$ & $\begin{array}{c}\text { Isolate } \\
\text { No. }\end{array}$ & $\begin{array}{l}\text { Gram's } \\
\text { reaction }\end{array}$ & $\begin{array}{l}\text { Degradat } \\
\text { Glucose }\end{array}$ & $\begin{array}{c}\text { on of char } \\
\text { Sucrose }\end{array}$ & $\begin{array}{l}\text { ohydrate } \\
\text { Lactose }\end{array}$ & $\begin{array}{c}\text { Nitrate } \\
\text { reduction }\end{array}$ & $\begin{array}{c}\text { Gelatin } \\
\text { hydrolysis }\end{array}$ & $\begin{array}{c}\text { Catalase } \\
\left(3 \% \mathrm{H}_{2} \mathrm{O}_{2}\right)\end{array}$ & $\begin{array}{c}\text { Casein } \\
\text { hydrolysis }\end{array}$ & $\begin{array}{c}\text { Starch } \\
\text { hydrolysis }\end{array}$ & $\begin{array}{c}\text { Methyl } \\
\text { red }\end{array}$ & $\begin{array}{l}\text { Urease } \\
\text { activity }\end{array}$ \\
\hline \multirow{7}{*}{ 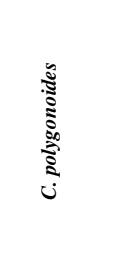 } & $\mathrm{T}-1$ & + & + & - & - & + & + & + & - & - & - & + \\
\hline & $\mathrm{T}-2$ & - & - & - & - & - & - & + & - & + & - & - \\
\hline & $\mathrm{T}-3$ & - & + & - & + & - & - & + & - & - & - & + \\
\hline & $\mathrm{T}-4$ & - & - & - & - & - & - & + & - & + & - & - \\
\hline & $\mathrm{T}-5$ & - & - & - & - & - & - & + & - & + & - & - \\
\hline & $\mathrm{T}-10$ & - & - & - & - & - & - & + & - & - & - & - \\
\hline & $\mathrm{T}-22$ & - & - & - & - & - & - & + & - & - & - & - \\
\hline \multirow{11}{*}{ 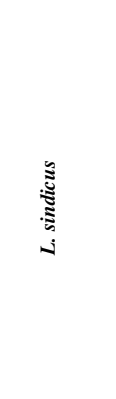 } & TS-1 & - & + & - & + & - & + & + & - & + & - & + \\
\hline & TS-2 & - & - & - & - & - & + & + & - & + & - & - \\
\hline & TS-4 & - & - & - & - & - & - & + & - & - & - & - \\
\hline & TS-5 & - & - & - & - & - & - & + & - & + & - & - \\
\hline & TS-11 & - & + & - & - & + & + & + & - & + & - & + \\
\hline & TS-12 & - & - & - & - & - & - & + & - & + & - & - \\
\hline & TS-13 & - & - & - & - & - & - & + & - & + & - & - \\
\hline & TS-16 & - & - & - & - & - & - & + & - & + & - & - \\
\hline & TS-17 & - & - & - & - & - & + & + & - & + & - & - \\
\hline & TS-18 & + & + & - & - & + & + & + & - & - & - & - \\
\hline & TS-20 & - & - & - & - & - & + & + & - & + & - & - \\
\hline
\end{tabular}

\section{Comparative analysis of the isolates of C. polygonoides and L. sindicus}

When all the rhizobacterial isolates from one plant were compared with another plant in terms of acetylene reduction activity, colonies isolated from $L$. sindicus were found to have a higher ARA. In case of $C$. polygonoides the isolates T-5 and T-1, showed higher ARA value (7594.8 and $4110.5 \mathrm{n}$ moles / $24 \mathrm{~h}$, respectively), while other isolates have ARA values in the range of 1600-2700 n moles / $24 \mathrm{~h}$. In case of the morphotypes isolated from L. sindicus, the lowest and highest values of ARA were detected in TS-11 and TS-13 (1688.7 and $8302.7 \mathrm{n}$ moles / $24 \mathrm{~h}$, respectively). The other isolates have ARA values more than $3000 \mathrm{n}$ moles / $24 \mathrm{~h}$.

It has been reported that the concentration of root exudates in the rhizotic zones is higher in case of plants belonging to gramineae family. These exudates generally consist of carbohydrates, organic acids, amino acids and amides, vitamins and other 
compounds $[10,11]$. The concentration of amino acids released by the plants are considered to be insufficient as a source of nitrogen to explain the increased microbial population in rhizosphere [18] indicating that nitrogen may be limiting for microbial growth in the rhizosphere, giving nitrogen fixers a potential advantage [2].

\section{Conclusions}

Various plant developmental processes are controlled by internal signals that depend on the adequate supply of mineral nutrients by soil to roots. Therefore, the availability of nutrient elements can be a major constraint to plant growth in many environments of the world, particularly in the hot arid areas where the soils are extremely low in nutrients. The potential of non-symbiotic $\mathrm{N}$ fixation can provide an improved solution in these areas to promote plant development. A better awareness and understanding of the role of non-symbionts in these areas would then be helpful in the development of bio-inoculum. The approach of developing the bio-inoculum for the studied areas looks appealing as the fertility of the soil may be increased by inoculating the best suited bacterial strain which intern will give rise to a better plant population in the natural conditions without applying fertilizer input from out side.

\section{REFERENCES}

[1] Bhatnagar, A. and Bhatnagar, M. (2005): Microbial diversity in desert ecosystems - Curr. Sci. 89: 91-100.

[2] Burgmann, H., Meier, S., Bunge, M., Widmer, F. and Zeyer, J. (2005): Effect of model root exudates on structure and activity of a soil diazotroph community - Environ. Microbiol. 7(11): 1711-1724.

[3] Calvaruso, C., Turpault, M. and Frey-Klett, P. (2006): Root-associated bacteria contribute to mineral weathering and to mineral nutrition in trees: a budgeting analysis - Appl. Environ. Microbiol. 72(2): 1258-1266.

[4] Faroda, A.S., Joshi, D.C. and Balak, Ram (1999): Agro-ecological zones of NorthWestern hot arid region of India - Central Arid Zone Research Institute, Jodhpur, Rajasthan, India.

[5] Gothwal, R.K., Nigam, V.K., Mohan, M.K., Sasmal, D. and Ghosh, P. (2006): Phosphate solybilization by rhizospheric bacterial isolate from economically important desert plants - Indian J. Microbiol. 46 (3): 273-279.

[6] Johri, B.N., Sharma A. and Virdi J.S. (2003): Rhizobacterial diversity in India and its influence on soil and plant health - Adv. Biochem. Eng. Biotechnol. 84: 49-89.

[7] Khathuria, N. (1998): Rhizosphere microbiology of desert - M. Sc. dissertation, Department of Microbiology, Maharshi Dayanand Saraswati University, Ajmer (Rajasthan), p. 52.

[8] King, E.O., Ward, M.K. and Rancy, D.E. (1954): Two simple media for the demonstration of pyocyanin and fluorescein - J. Lab Clinical Medi. 44: 301-307.

[9] Kloepper, J.W. (1997): Current status and future trends in Biocontrol Research and Development in the U. S. - In: International symposium on clean agriculture, Sapporo, DECD, p. 49-52.

[10] Kuiper, I., Kravchenko, L.V., Bloemberg, G.V. and Lungenberg, B.J.J. (2002): Pseudomonas putida strain PCL 1444, selected for efficient root colonization and naphthalene degradation, effectively utilizes root exudates components - Mol. Plant Microbe Interact., 15: 734-741. 
[11] Lunch, J.M. and Whipps, J.M. (1990): Substrate flow in the rhizosphere - Plant Soil, 129: $1-10$.

[12] Muthukumarasamy, R., Revathi, G., Seshadri, S. and Lakshminarsimhan, C. (2002): Gluconacetobacter diazotrophicus (syn. Acetobacter diazotrophicus) endophyte in tropics - Curr. Sci. 83(2): 137-145.

[13] Okon, Y., Albrecht, S.L. and Burris, R.H. (1977): Methods of growing Spirillum lipoferum and for counting it in pure culture and in association with plants - Appl. Environ. Microbiol. 33: 85-88.

[14] Pareek, R.P., Chandra, R. and Pareek, N. (2002): Role of BNF technology in sustainable agriculture -- Proceedings of National symposium (eds. Masood, A., Chaturvedi, S.K. and Gurha, S.N.), Indian Institute of Pulses Research, Kanpur, p. 33-42.

[15] Postgate, J. (1998): Nitrogen fixation - $3^{\text {rd }}$ Ed., Cambridge University Press, Cambridge, U. K.

[16] Rao, A.V. (2000): Soil biotechnological approaches for sustainable agricultural production in India arid zone - Microbiotech 2000, $41^{\text {st }}$ Annual Conference, Association of Microbiologists of India, $6 \mathrm{p}$.

[17] Seeley, H.W., Vandemark, P.J. and Lee, J.J. (1991): Microbes in Action - A Laboratory Manual of Microbiology. WH Freeman and Company, New York.

[18] Simons, M., Permentier, H.P., deWeger, L.A., Wijffelman, C.A. and Logtenberg, B.J.J. (1997): Amino acid synthesis is necessary for tomato root colonization by Pseudomonas fluorescens strain WCC 365 - Mol. Plant Microbe Interact., 10: 102-106.

[19] Tilak, K.V.B.R., Ranganayaki, N., Pal, K.K., Saxena, A.K., Nautiyal, C.S., Mittal, S., Tripathi, A.K. and Johri, B.N. (2005): Diversity of plant growth and soil health supporting bacteria - Curr. Sci. 89: 136-149.

[20] Venkateswarulu, B. and Rao, A.V. (1981): Distribution of microorganisms in stabilised and unstabilised sand dunes of Indian desert - J. Arid Environ. 4: 203-208. 